\title{
Konya Akşehir Taş Medresesinin Taş Eserler Müzesine Dönüşümü
}

\author{
Şebnem ERTAŞ* \\ Karadeniz Teknik Üniversitesi, Mimarlık Fakültesi, Mimarlık Bölümü, 61080, Trabzon, Türkiye. \\ *e-mail:sebnemarc@hotmail.com
}

\section{Öz}

Medrese yapıları, kültürümüzün birer parçası ve geçmişimizi yansıtan eserlerimiz arasında yer almaktadır. Ancak geçen zamanla birlikte değişen şartlar, binaların işlevlerinin yok olmasına sebep olabilmektedir. Bu yapıların günümüzde tekrardan kazandırılması hem toplum yararına olacaktır, hem de yapının zaman içinde yok olmasını önleyecektir. Çalıssma kapsamında günümüzde Konya'nın Akşehir ilçesi için önemli bir kültür mirası olan Sahaib-i Ata Fahrettin Ali (Taş) Medresenin müze olarak yeniden işlevlendirmesi ile tefriş ve tanzim projesinin tasarım süreci ele alınmıştır. Bu kapsamda, yapının restorasyonu sonrası hem kendisi hem de medrese işlevinin sergilenmesi gereken bir özellik olması nedeniyle izlenilen (araștırma süreci ve senaryo süreci, mekan organizasyon seçeneklerin oluşması, sergileme elemanlarına yönelik seçeneklerin oluşturulması) aşamalar incelenmiştir. Tüm çalışmalar, bir kültür varlığı olan medrese binasının yeniden kullanımı amacıyla dönüşüm sürecinde restitüsyon ve restorasyon çalışmalarının önemine vurgu yapmıştır. Ayrıca teşrif ve tanzim projelerinin hangi aşamalarda hazırlandığını ortaya koymayı hedeflemiştir.

Anahtar Kelimeler: Sahaib-i Ata Fahrettin Ali (Taş) Medresesi, kültür varlığı, yeniden kullanım, müze tasarımı

\section{Conversion of Konya Akşehir Stone Madrasah to Stone Works Museum}

\begin{abstract}
The madrasa constructions are part of our culture and are among our works reflecting our past. However, the changing circumstances along with the passing time have caused the disappear of the functions of the buildings. It will be beneficial for the society to gain these structures from now on, and it will prevent the building from disappearing over time. Within the scope of the study, the design process of the furnishing and designing project was handled with the re-functioning of Sahaib-i Ata Fahrettin Ali (Stone) Madrasah, which is an important cultural heritage for the city of Akşehir in Konya. In this context, since the restoration of the structure is a feature that must be exhibited both itself and the madrasah function (research process, scenario process). All studies have emphasized the importance of restitution and restoration work in the conversion process in order to reuse the madrasa building, which is a cultural asset. He also aimed to reveal the stages in which the projects and arrangements were prepared.
\end{abstract}

Keywords: Sahaib-i Ata Fahrettin Ali (Stone) Madrasah, cultural asset, re-use, museum design

\section{Giriş}

Önemli bir kültür kaynağı olan mimarinin sürdürülebilirliği, koruma ve restorasyon çalışmalarının yapılması ile mümkündür. Kültür varlıklarına; sosyal, ekonomik ve teknolojik değişmeler sonucu ortaya çıkan yeni istek ve gereksinmeleri karşılayamaz duruma geldiğinde, sürekliliği için yeni fonksiyonlar yüklenebilir (Üçer, 2011). İ̧̧levini kaybeden bu yapı türleri, yapısal ömürlerini tamamladıkları için yeniden işlevlendirmeye uygun yapılar olarak karşımıza çıkmaktadır (Sinan, 2011).

Büyük bir potansiyele sahip olduğu halde hızlı bir yok olma sürecine giren ve gereği gibi değerlendirilemeyen kültür mirasının koruma-kullanma-yaşatma ilkeleri doğrultusunda sürdürülebilirliğini sağlamak için ülkemizde bir takım çalışmalar yapılmaya başlanmıştır (Emekli, 2005). Kültürel mirasın korunması ve yaşaması için birincil gereklilik, tarihi yapıların günümüz kullanımına 
entegre edilebilmeleridir. Bu bağlamda sürdürülebilirliğinden bahsedilebilir. Yapıların, konumlandıkları çevresel verileri, mekan organizasyonları, korunmuşluk durumları, yasal statüleri göz önünde bulundurularak, yapılar yeniden işlevlendirilir ve günümüz mekanlarına dönüştürülür. Bu dönüşüm sürecinde yapılara giydirilen bu yeni fonksiyonlar yapıların özgün işlevleri ile örtüşebilir ya da aykırılıklar içerebilir (Tanaç Zeren, 2010).

Yapıların sahip olduğu işlevler, toplumun sosyal, kültürel, ekonomik özellikleriyle etkileşim içindedir. Bu özellikler değiştikçe yapıdaki işlev de etkilenir. Fakat önemli olan nokta, bu işlev etkileşimi sırasında tarih belleğini simgeleyen kavramların sürekliliğinin sağlanmasıdır (Sinan, 2011). Bu bağlamda, günümüzde eski ve artık kullanılmayan bu yapılar, bulundukları konum, $\mathrm{m}^{2}$, çevresel ve ekonomik faktörler ya da sosyal nedenlerle müze, okul, kamu binası, ticari bina vb. gibi işlevlerde kullanılabilmektedir. Örneğin, Almanya'da Bonn'da, Ludwig van Beethoven'ın ve Avusturya'da Salzburg'da da Wolfgang Amadeus Mozart'ın doğdukları evler, günümüzde müze olarak kullanılmakta olup, şehirler için bir simge olmuştur (Şekil 1). Türkiye'de Konya Selçuklu Belediyesi tarafından gerçekleştirilen "Tarihe Vefa" projesi ile Aya Eleni Kilisesi restore edilerek müze olarak kullanıma açılmıştır (Şekil 2). Böylelikle kültür turizmini canlandırarak, yapının sürdürülebilirliği sağlanmak istemiştir. Bu ve benzeri çalışmalar dünyada ve ülkemizde kültür varlıklarının onarılarak yeniden kullanımı ile gelecek yüzyıllara aktarımını sağlayan önemli bir ekonomik kaynak olmuştur.

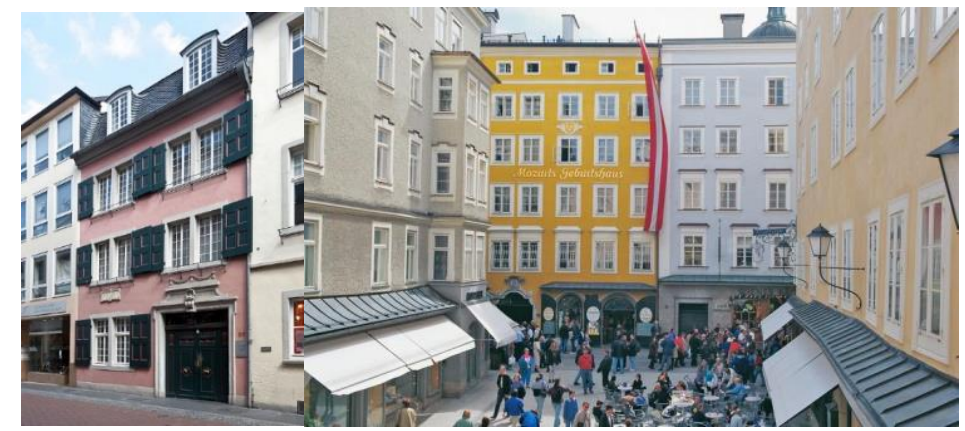

Şekil 1. Almaya/ Bonn, Beethoven evi; Avusturya/Salzburg, Mozart'ın doğduğu ev (URL-1), (URL-2)

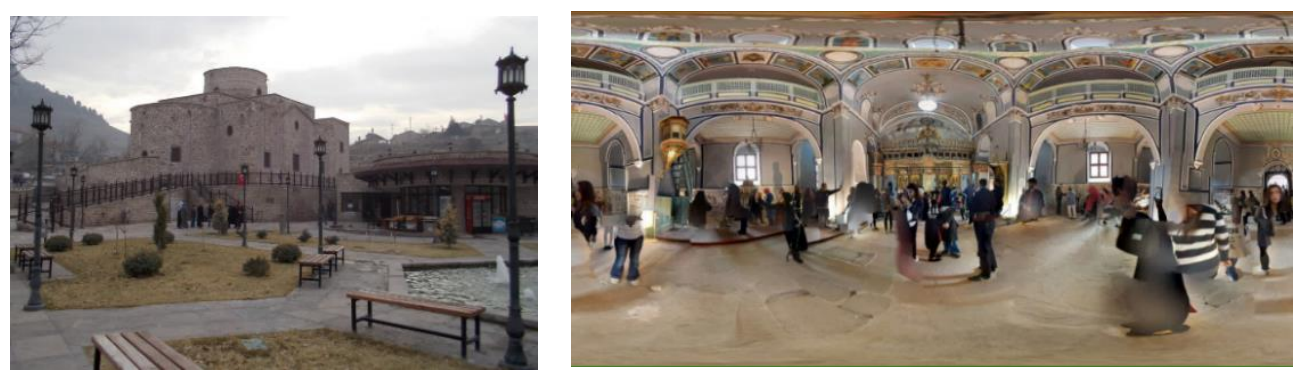

Şekil 2. Aya Eleni klisesi (Kişisel Arşiv, 2016)

Günümüzde ülkemizde saray, medrese, kervansaray gibi bazı yapılar, özgün işlevlerini tamamen kaybettikleri için işlevleri eskimektedirler. Yapıların fiziksel özelliklerinin işlevlerinden daha ömürlü oldukları düşünülürse, işlevlerini sürdüren binalar için bile, her konudaki gelişmeler nedeniyle sorunlar oluşabilmektedir. Bu nedenle o binaya ait işlevin tamamen değiştirilmesi ya da işlevin geliştirilmesi gerekebilir (Altınok, 1998). Yapıların büyük bir çoğunluğunun tarihsel gelişimine bakıldığında müze, restoran, okul, kamu binası, banka, ticari bina vb. gibi farklı işlevlerde yeniden kullanımı oldukça doğal bir süreç gibi adeta kendiliğinden gerçekleşmektedir. Bu sebeple çalışmada, kültür varlıklarının yaşadıkları sürdürülebilir gelişim ve değişim süreci ele alınmış, bu süreç medrese yapısı özelinde müze işlevi verilmesiyle işlevsel ve biçimsel anlamda irdelenmiştir.

Medreseler Türklerin İslamiyet'ten sonra geliştirdikleri en önemli yapılardandır. Türk mimarisinin gelişim çizgisi içerisinde, bu gelişime katkıda bulunan ve başından sonuna kadar tutarlı bir gelişim gösteren medrese yapılarının en güzel örnekleri, Anadolu Selçukluları döneminde özellikle Konya'da yapılmıştır (Yaldız, 2003). Bu yapılar; 8 yy. başlarında kurulmaya başlanmış, 12.yy başlarında bilime öncülük etmiş, 16 yy'dan sonra bozulmaya başlamıştır. Osmanlı döneminde medrese tarihinde 
modernleşme dönemi ise batı tipi yüksek öğretim kurumlarının açılması ile olmuş, ancak 19. yy'da bozulmaya başlamıştır. Cumhuriyet döneminde ise 1924 yılında medreselerin kapatılması kararı verilmiş, 1925 yılına kadar bütünüyle kapatılmıştır. Böylelikle medreseler işlevini kaybetmişlerdir. Korunması gereken bir kültür mirası olan medreseler, durumlarına göre taşınmaz, türlerine göre dini, zaman içerisindeki yerlerine göre de işlevini yitirmiş yaşayan anıtsal binalardır. Medrese yapıları anıt özelliği taşıdığı için 1. derece yapı grubuna girmekte ve aynen korunması gerekmektedir (Yaldız, 2003). Bu kapsamda bir kültür varlığı olan medreseler, günün gerektirdiği çağdaş kullanımlara uyarlanması gereken bir yapı türü olup, müze olarak kullanılması durumunda işlevlendirme aşamasında önerilen mekanlar ve oluşturulan senaryonun yapı ile uyumuna dikkat edilmelidir.

Müzeler, ilk örneklerinden günümüze kadar, her türden bilgi ve belgeyi toplayan, koruyan, düzenleyen ve sunan kurumlar arasında olup bir amaç doğrultusunda üretilmiş kültür ve sanat ürünlerini gelecek kuşaklara aktarmada köprü işlevi üstlenen kurumlardır (Dedehayır, 2013).

Müze kelimesi, köken olarak Yunan mitolojisindeki Mouseion'dan gelir. Yunan mitolojisinde Mouseion, müzelerin yaşadığı yer, müzelere adanmış olan anlamındadır. İnsanoğlunun beslenme, barınma ve korunma gibi temel ihtiyaçlarını karşılama içgüdüsüyle başlayan toplama/biriktirme isteği, yüzyıllar içinde, her türlü nesne ve sanat eserini içeren büyük bir birikim oluşturmuştur. Bu birikimin temelinde yer alan toplama etkinliği, belli bir amaca yönelik, düzenli ve sistemli bir eyleme dönüştüğünde önce koleksiyonların sonra da günümüz müzelerinin ortaya çıkmasına neden olmuştur (Öztekin, 2014).

Bir kültür varlığının müze olarak kullanılmasının seçiminde genellikle iki yol izlenmektedir. Bunlardan ilki, müzenin niteliğinin ve gereksinmelerinin belirlenip, buna uygun bir binanın seçilmesidir. Bu koruma/kullanma dengesinin sağlanması ve yapı/işlev uyumuna ulaşılabilmesi için en doğru yaklaşımdır. İkinci yaklaşım ise, belli bir program oluşturulmadan çeşitli nedenlerin etkisiyle belirlenmiş bir yapıya, müze işlevinin uyarlanmak istenmesidir. Türkiye'de genellikle bu ikinci yaklaşım daha çok kullanılmaktadır. İ̧̧levlendirme aşamasında ise aşağıdaki dört temel ilke önem taşımaktadır (Sinan, 2011).

1. İşlevlendirme sırasında, yapının tüm mimari, mekânsal ve bezeme özellikleri korunmalıdır.

2. Kültür mirası yapıların, sadece belirli işlevleri üstlenebildiği unutulmamalıdır.

3. Yapının da sergilenmesi gereken bir eleman olduğu unutulmamalıdır.

4. Bir müze işlevi için gerekebilecek her tür teknik donanımın yapının özgün bünyesine zarar vermeyecek ölçek ve nitelikte tasarlanmasına çalışıımalıdır.

Bu bağlamda çalışmada Konya Akşehir'de yer alan Taş Medrese yapısının restorasyonu sonucunda yeniden müze olarak kullanılması ile teşrif ve tanzim projelerinin değerlendirilmesi ele alınmaktadır.

\subsection{Konya Akşehir Sahaib-i Ata Fahrettin Ali (Taş) Medrese}

Akşehir Konya'nın 135 km kuzey- batısında, Konya-istanbul karayolu ile Anadolu-Bağdat demiryolu üzerinde yer alan büyük bir ilçesidir. Önemli bir tarihi geçmişe sahip olan Akşehir'in Bizans Döneminde (M.S. 395-1146) de "Akşehir" adının "Aqşehir" olduğu Türklerin eline geçtikten sonra "Akşehir" adını aldığı bilinmektedir. Emeviler, Selçuklular ve Osmanlılar hüküm sürmüştür. Cumhuriyet dönemimde de önemli bir yer olan Akşehir özelliklede askeri zaferlerin kazanılmasında stratejik konum olarak önemli bir yer oynamıştır (Şekil 3). 


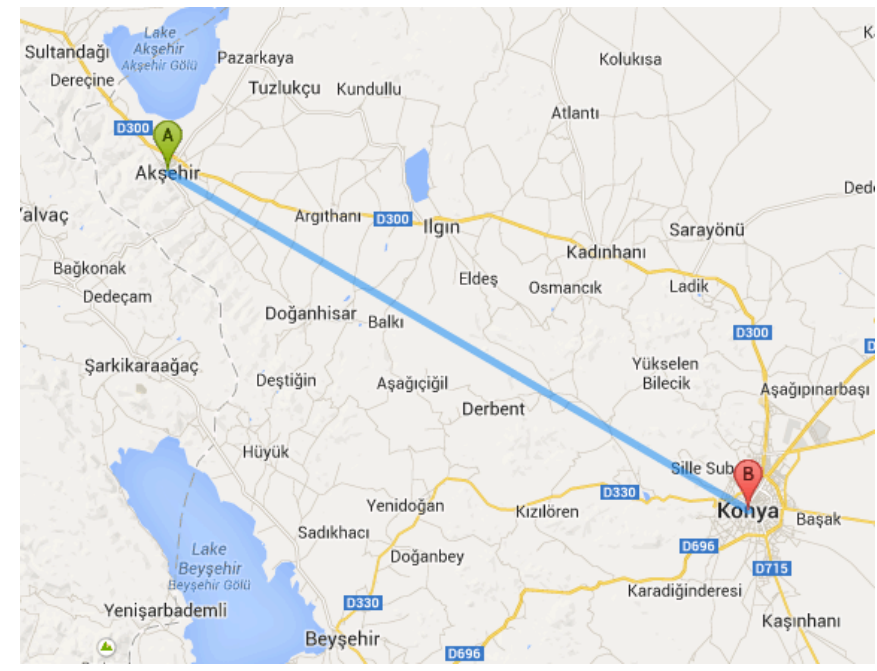

Şekil 3. Akşehir Konumu (URL-3)

Selçuklular Döneminde Portalin üzerindeki kitabeye göre Hicri: 648, Miladi: 1250 yılında II. Keykavus'un hükümdarlığı zamanın da Vezir Sahip Ata Fahreddin Ali tarafından Akşehir'i önemli bir ilim ve kültür merkezi yapmak için Taş Medrese yaptırılmıştır (Frıedrıch, 1896) (Şekil 4).

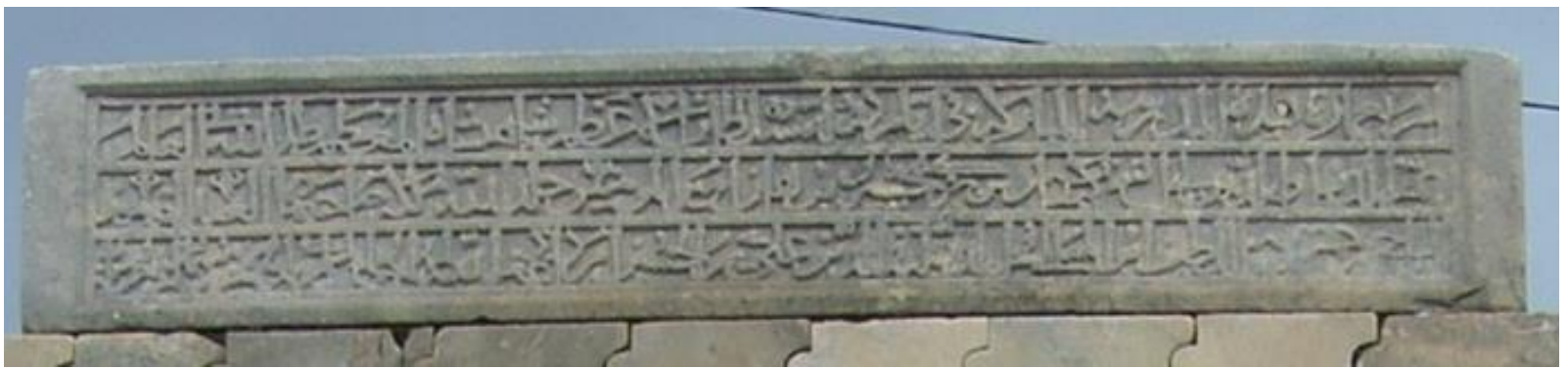

Şekil 4. Medresenin portalde yer alan kitabesi (Restitüsyon raporu, 2009),

Akşehir Sahaib-i Ata Fahrettin Ali (Taş) Medrese Altınkalem Mahallesi Eski Afyon Caddesi üzerinde yer almaktadır. Bir külliye olarak inşa edilmiş manzumeden Hankah, imaret, çeşme ve hamam yıkılmıştır (Aslanapa, 1973). Medrese, türbe, iki şerefeli minare, darülkurra ve mescit günümüze ulaşmıştır (Köroğlu, 1999). Bazı Selçuklu medreselerinde görülen bitişik mescit uygulaması İnce minarede "Halkalı Medrese" olarak da bilinen taş medresede görülmektedir (Demiralp, 1996), (Ara, 1998) (Şekil 5).

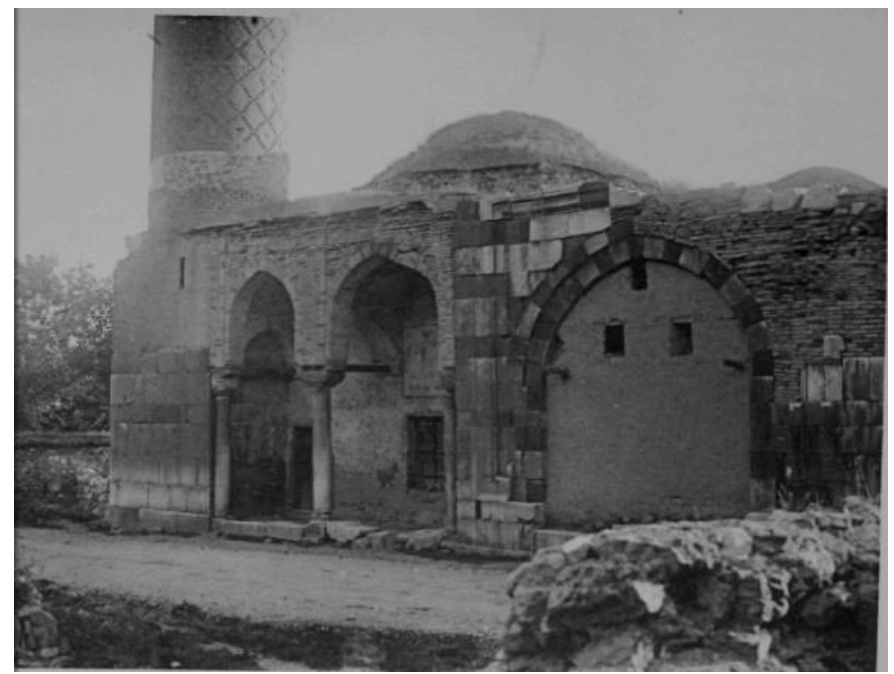

Şekil 5. Akşehir Taş Medresenin mescit ve medresenin görünüşü (Sarre, 1896)

\subsubsection{Taş Medresenin Planı}

Medrese genel olarak doğu-batı doğrultusunda uzanan, dikdörtgene yakın bir plan şemasına sahiptir. Ancak giriş cephesinin kuzey ve güney ucuna eklenen yapılarla bu plan şeması ters " $\mathrm{T}$ " şeklini almıştır. 
Giriş cephesinin güney ucundaki, kareye yakın dikdörtgen plana sahip mekanın yalnızca bir kısmı ayaktadır. Bu duvarlardan özellikle kuzeydekinin ilk inşaattan olup olmadığı kesin değildir. Bu anlamda da türbe ve mescidin ilk yapıya ait olduğu sanılmaktadır. Bu mekana giriş batı duvarındaki düz atkı taşlı açıklıktan sağlanmıştır. Devşirme malzemeden sövelere çevrili açıklığın üstünde bezemeli bir Bizans mimari parçası yer almaktadır. Bu mekan için Aptullah Kuran (1969) ve Haşim Karpuz (1994) Darülkurra olduğunu söylemektedir. Ancak üst örtüsü günümüzde mevcut olmadığından nasıl bir örtüye sahip olduğu konusunda kesin bir bilgi yoktur. 1965- 66 yıllarında Vakıflar Genel Müdürlüğünce kabul edilen onarım programı ile mescit, türbe ile bu bölümdeki revakların içine alan bir planlama yapılııştır. Bu onarım bir dereceye kadar yapıyı tarihi biçime yaklaştırdıysa diğer onarımla birlikte yapıda değişmeler görülmüştür (Restitüsyon Rapor, 2009) (Şekil, 6).

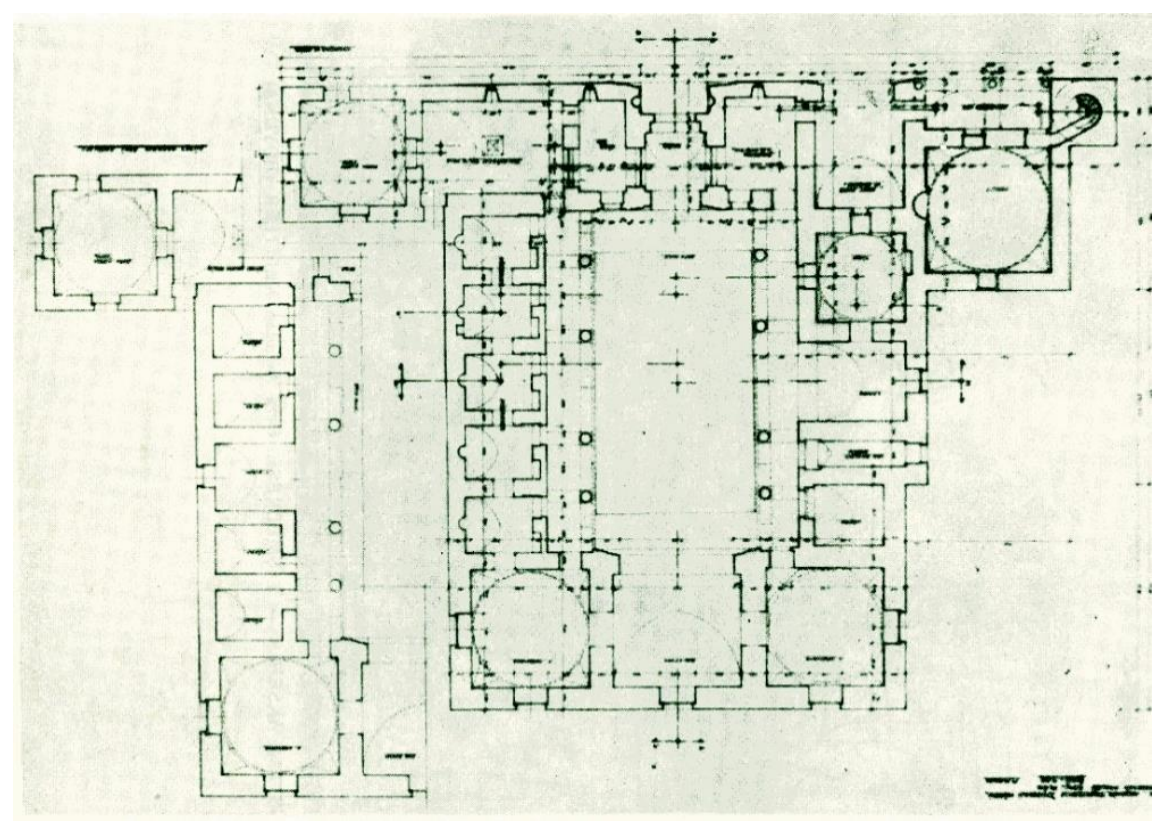

Şekil 6. Taş Medrese'nin planı (Akok, 1979)

Medresede yapılan değişimler arasında sol eyvan kaldırılmış ve onun yerine bir oda daha yapılmıştır. Ayrıca girişin sağındaki ve solundaki türbe evyanı ile türbe duvarlarında orijinal durumuna göre farklııklar görülmüştür (Restitüsyon raporu, 2009) (Şekil 7).

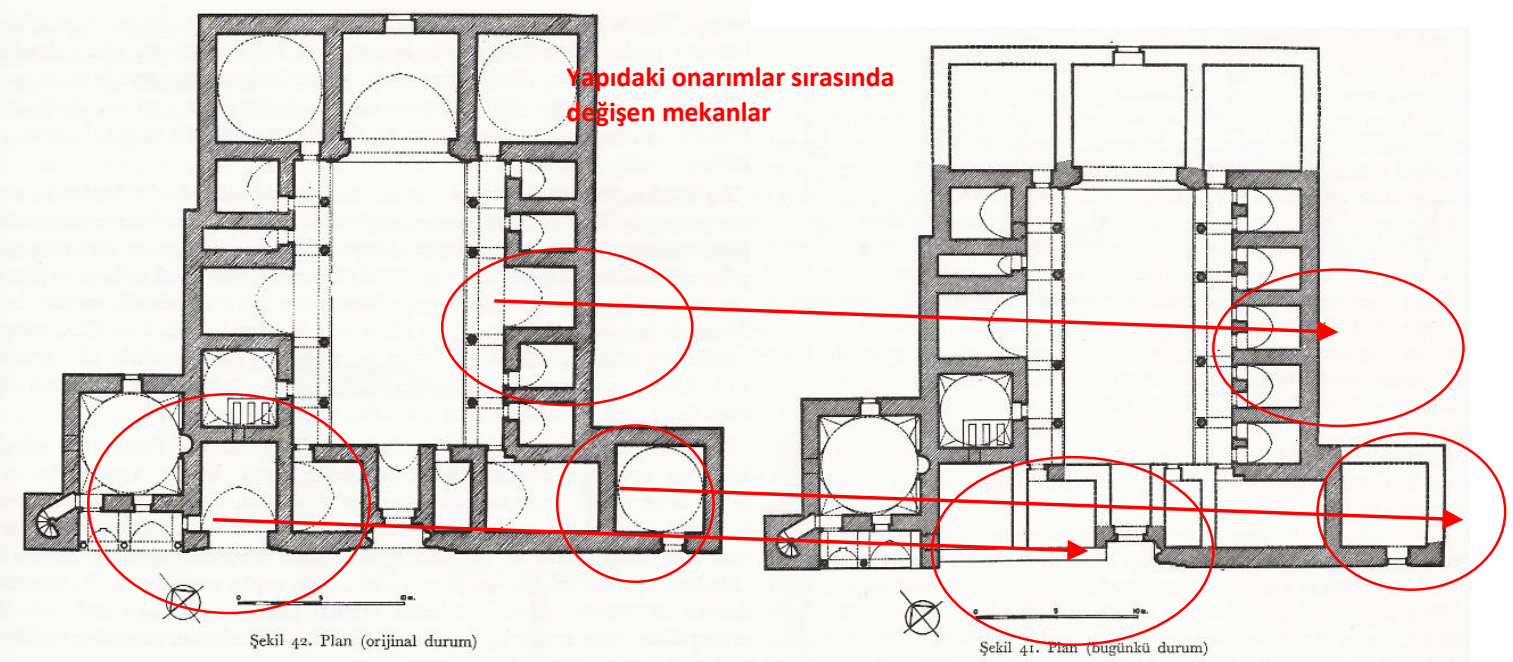

Şekil 7. Medresenin iki ayrı dönemdeki planları (Kuran, 1969; Restitüsyon raporu, 2009)

Yapının planını iki gurupta incelemek mümkündür. Çünkü yapının çeşitli dönemlerde onarılması farklı planların oluşmasına neden olmuştur. Bu anlamda da Taş medrese, tek katlı üç veya dört eyvanlı açık avlulu medrese olarak kabul görmüştür (Eroğlu, 2003). 
Dört eyvanlı plan şemasının Selçuklu Medreselerinde fazlaca görülmektedir. Kayseri'deki Çifte Medrese ile Sahibiye Medresesi, Sivas'taki Burûciye Medresesi, Gök Medrese dört eyvanlı yapılardır. Akşehir de bulunan Taş Medresenin de aslında dört eyvanlı bir yapı olması kuvvetle muhtemeldir (Restitüsyon Rapor, 2009) (Şekil 8).

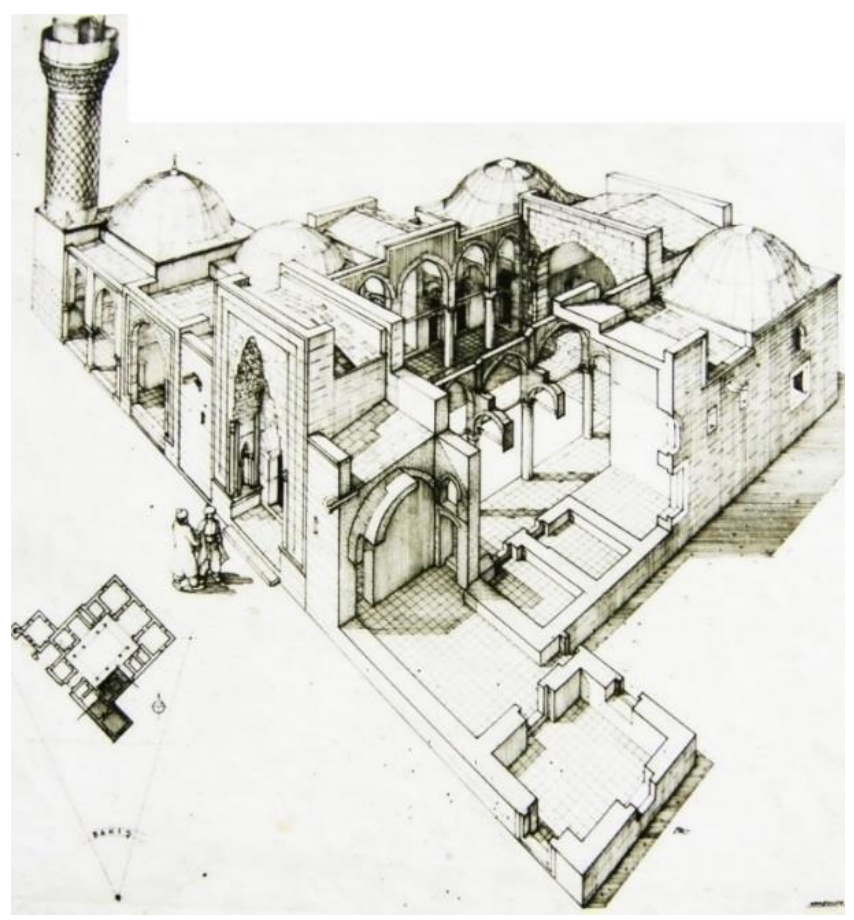

Şekil 8. Akşehir Taş Medrese'nin rekonstrüksiyon çizimi (Akok, 1979)

\subsubsection{Taş Medresede Kullanılan Malzeme ve Süsleme Özellikleri}

Akşehir Taş Medresede yapım malzemesi olarak taş, mermer ve tuğla ilk olarak göze çarpmaktadır. Zaten Selçuklu medreselerin ana yapım malzemesi ağırlıklı olarak taş ve mermer, üst örtüde ise tuğla malzeme kullanılmıştır (Şekil 9).

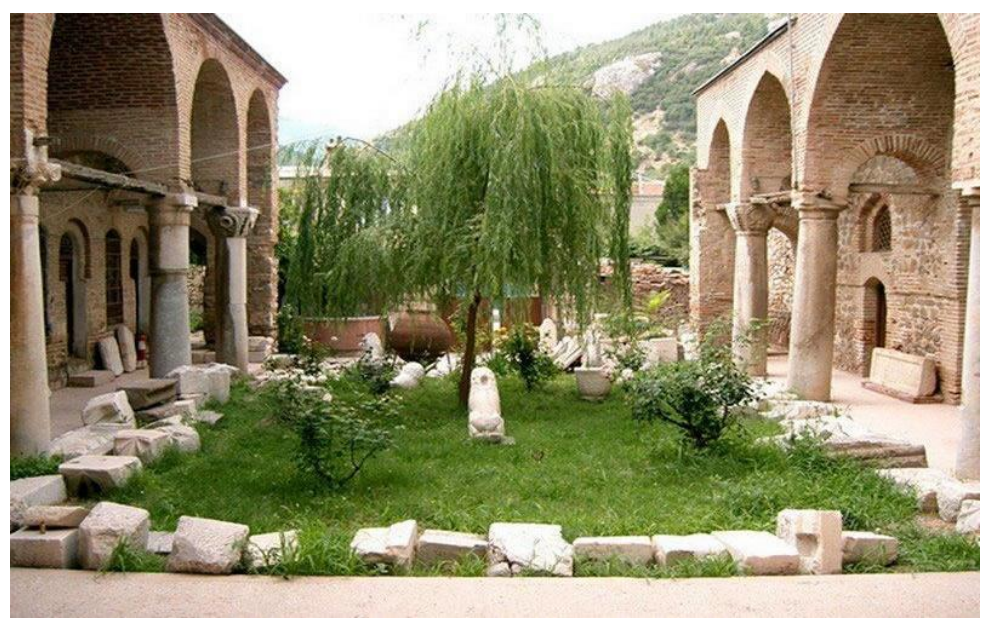

Şekil 9. Taş Medresenin iç avlusunun taç kapıya doğru görünüşü (Restitüsyon Rapor, 2009)

Özellikle yapının sokağa bakan cephelerinde mermer malzeme taç kapıda diğer Selçuklu yapılarında olduğu gibi tercih edilmiştir. Bunun yanında cephede zeminde taş üst kısımlara doğru kubbe ve kemerlerde tuğla kemer gergilerinde ise ahşaplar tercih edilmiştir. Bunun yanın da çini ve demir malzeme yapının farklı mekanlarında karşımıza çıkmaktadır (Şekil 10). 


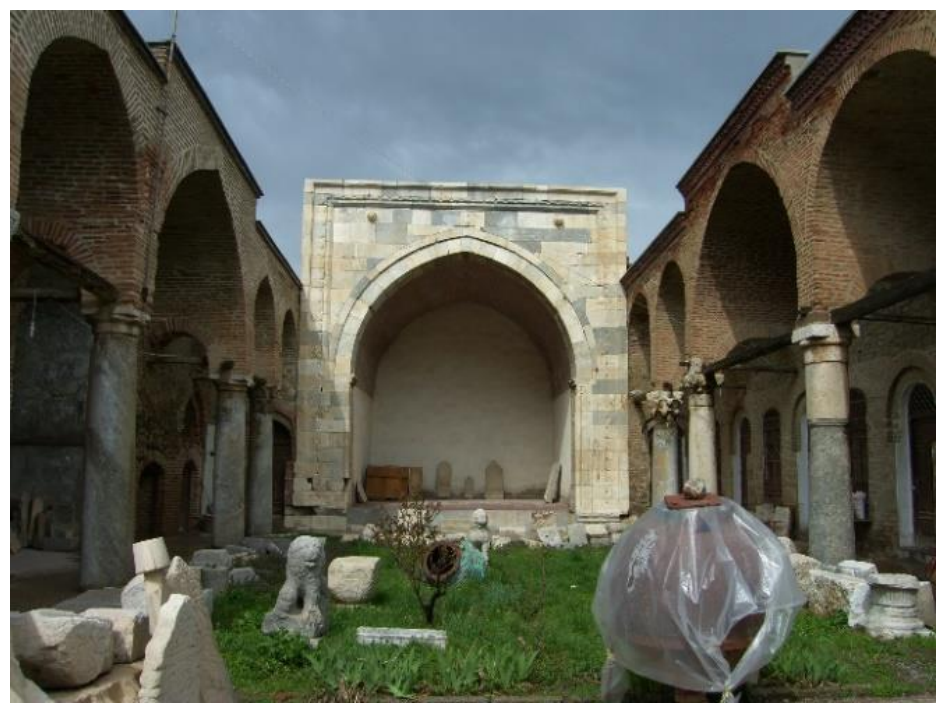

Şekil 10. Medresenin iç avlusundan ana eyvana doğru görünüş (Restitüsyon Rapor, 2009)

\subsubsection{Konya Akşehir Sahaib-i Ata Fahrettin Ali (Taş) Medresesinin müzeye dönüştürülme süreci}

Konya Akşehir Taş Medresesi, 2009 yılı öncesi Arkeoloji Müzesi olarak hizmet vermiştir. Ancak yapı harap bir durumda olmasından dolayı restorasyon çalışmalarına başlanılmasına karar verilmiş, sonrasında 09.09.2009 gün ve 3296 sayılı kurul kararları ile restorasyon ve restitüsyon projeleri ile taç kapı sistem detayı paftası ve raporu onaylanmıştır. Yapılan restorasyon projesine göre, aşağıdaki plan şeması kabul edilmiştir (Şekil 11).

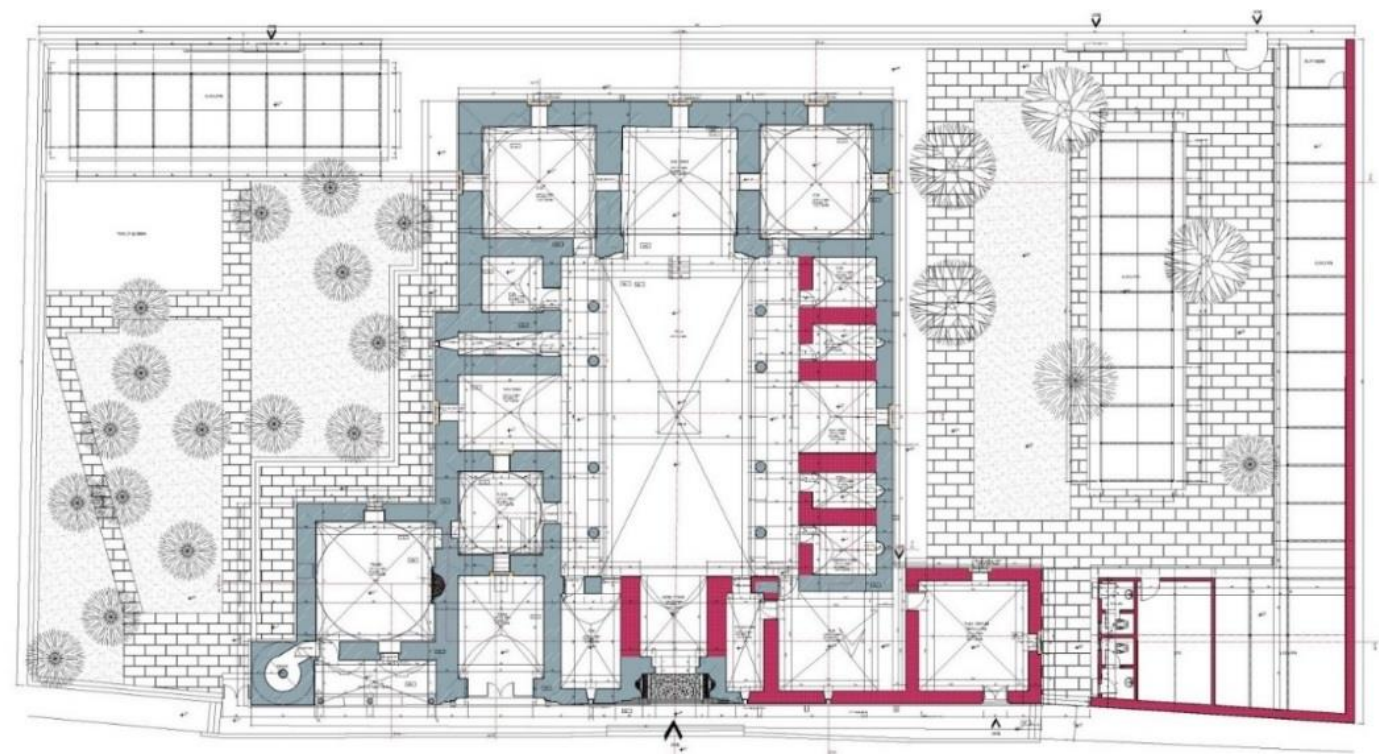

Şekil 11. Restorasyon tadilat projesi

Bu bağlamda; restorasyonu sırasında temeli açılarak sol eyvannın karşısında benzer bir eyvan olduğu görülmüş ve restorasyon projesinde de yer aldığı gibi mevcutta oda olan mekan, sağ eyvan olarak inşa edilmiştir. Ayrıca türbe eyvanı ve giriş kısmında, fotoğraflar, farklı planlar ve benzer medrese planlamalarına bağlı olarak aslına uygun şekilde yeniden yapılmıştır. Restorasyon tadilat raporuna göre (2009) uygulama sırasında ise;

Yapının ana eyvanın da yapılan sıva raspası sonrası her hangi bir pencere izine rastlanılmamakla birlikte bu bölümdeki eski restorasyon projesinde gösterilen pencere kaldırılmıştır.

Yapıya girişi sağlayan taç kapı kenarındaki mihrabiye üzerindeki mimari plastiklerin buraya ait olmadığı tespit edilerek fotoğraftaki özgün haline göre proje yenilenmiştir.

Yapını bahçesinde zemin doğu ve güneyindeki zemin kotuna bağlı olarak bu bölümlere engelli rampası yapılmıştır. 
Yapının güneyindeki bahçede yapılan sundurma medresenin ana duvarına doğru kaydırılarak orta bölümde geniş bir alan bırakılmıştır (Şekil 12).

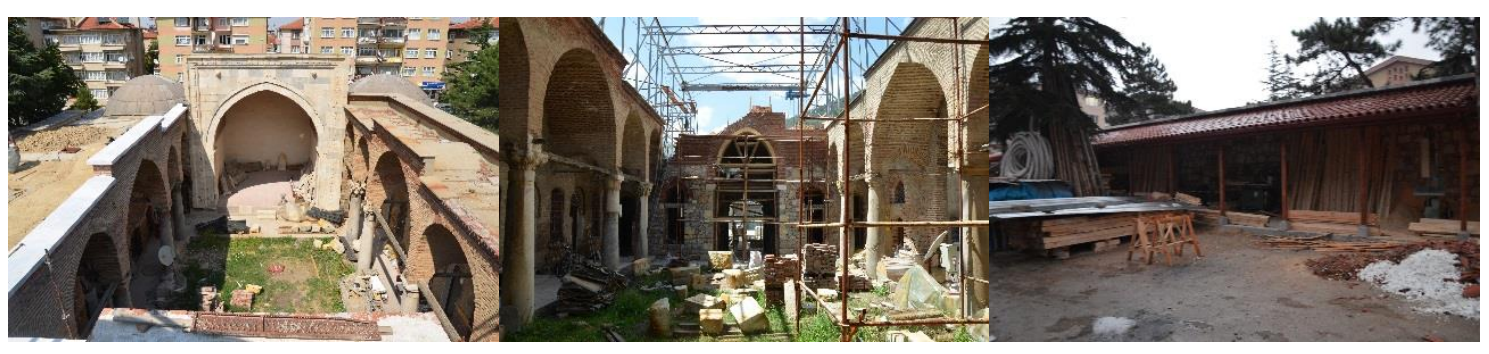

Şekil 12. Restorasyon süreci

Yapılan bu çalışmalar sonrası, Kültür Bakanlığı ve Müzeler Genel Müdürlüğünce; medrese yapısı için "Akşehir Taş Medrese Taş Eserler Müzesi" adı altında yeniden düzenlenmeye gidilmiştir. Bu bağlamda inşasına başlanılan yapının konumu, $\mathrm{m}^{2 \prime}$ si, yeniden belirlenen koleksiyona göre gerekli açık ve kapalı olanın bulunması, yapının restorasyonu sonrası hem kendisi hem de medrese işlevinin sergilenmesi gereken bir özellik olması nedeniyle teşhir ve tanzim projesi hazırlanmasına başlanmıştır. Bu bağlamda aşağıdaki şema izlenerek bir yol izlenilmiştir.

- Araştırma Süreci

- Yapıya Yönelik Araştırmalar

- Koleksiyonların Seçimi

- Senaryo Süreci

- Mekan organizasyon seçeneklerin oluşması

- Sergileme elemanlarına yönelik seçeneklerin oluşturulması

Araştırma sürecinde, yapının restorasyon projesi hazırlanmadan önce geçirmiş olduğu değişimler incelenmiştir. Sonrasında restitüsyon ve restorasyon raporları incelenerek yapının yeni işlevi ile uyumunun sağlanması amacıyla değerlendirmeler yapılmıştır. Böylelikle müze içinde hem medrese yapısının orijinal işlevinin yansıtıldığı hem de müze müdürlüğünün topladığı Figürlü mezar taşları, önemli şahsiyetlerin mezar taşları, çiniler, sütun başlıkları, kaideler, mezar steller, kısmi lahitler, mimari plastikler (Arşitrav, lento, söve vb.) vb. ürünlerin sergilenmesine karar verilmiştir. Bu bağlamda bu eserlere yönelik mekânsal düzenlemelere geçilmiştir.

Senaryo sürecinde, yapının medrese kimliğinin anlatılabileceği mekanlar ile koleksiyonların sergilenebileceği alanlar belirlenerek yerli ve yabancı ziyaretçilerin yaya ya da araçla ulaşım durumlarına göre müze girişleri düzenlenmiştir. Süreçte iki farklı seçenek hazırlanmıştır. İlgili görevlilerle birlikte yapılan toplantılar sonucu, hem fonksiyonel, hem sirkülasyon, hem de tefriş ve tanzim açısından kullanışı ılmasından seçenekler arasından oluşturulan en uygun senaryoya karar verilerek Sahaib-i Ata Fahrettin Ali (Taş) Medresesine ait tefriş ve tanzim projesi hazırlanmıştır. TC. Kültür ve Turizm Bakanlı̆̆ı Konya Kültür Varlıklarını Koruma Bölge Kurulu’nun 06.1.2015-147 toplantı tarihi ve numaralı, 06.11.2015-3232 karar tarihi ve numaralı ekte kurul kararı ile de kabul edilmiştir (Şekil 13). 

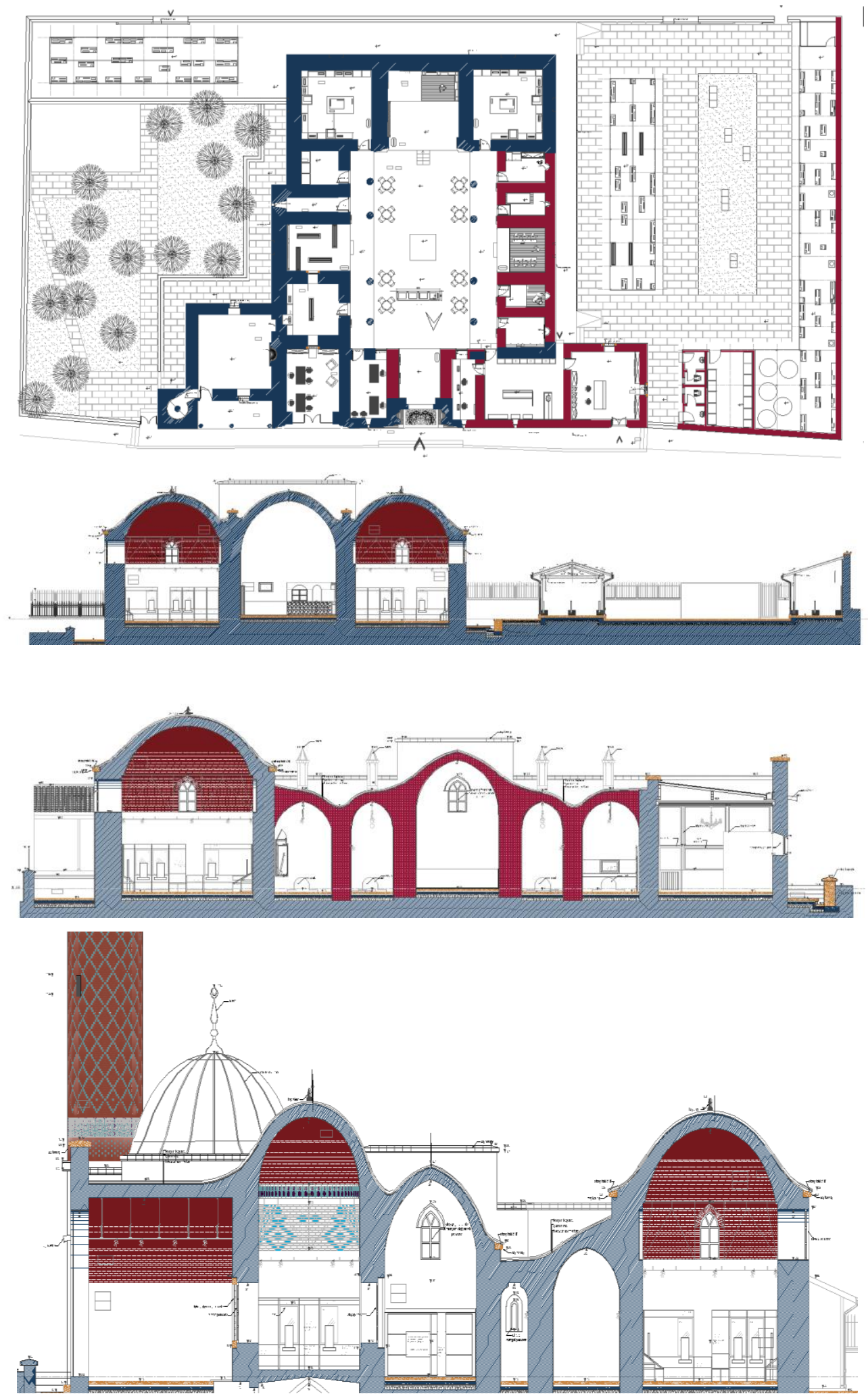

Şekil 13. Teşhir ve tanzim projesi plan ve kesiti

Belirlenen işlevlerde temel olarak medresenin sağ tarafı medrese eğitimini anlatan sol tarafı ise figürlü taşlardan oluşan koleksiyonlardan oluşmaktadır. Bu bağlamda müze için oluşturulan mekan organizasyonu aşağıdaki gibidir (Şekil 14). 


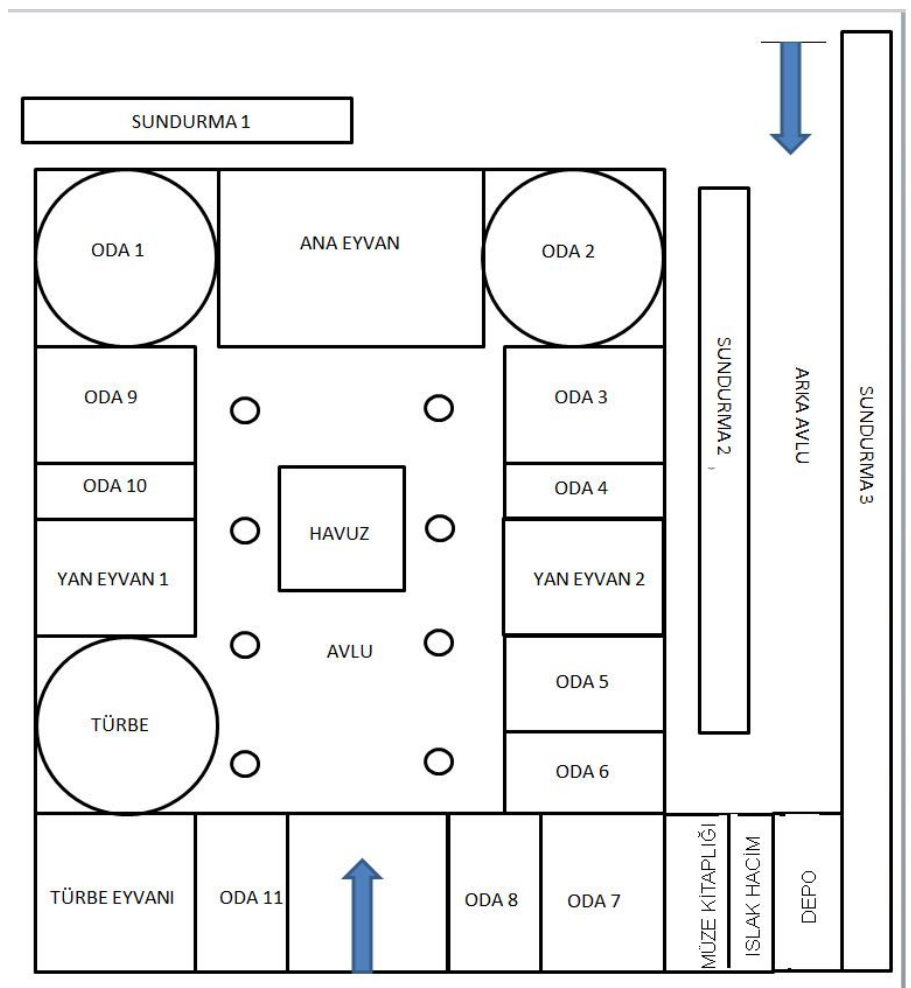

Şekil 14. Müze Odalarının numaralandırılması ve fonksiyon verilmesi

Ana Eyvanda, taş iş̧iliğini anlatan bir canlandırma ile buna yönelik bir bilgilendirme panosu tasarımı yapılıışı ı (Şekil 15, 16). Canlandırma yapılacak olan alanın yanında taşın ocaktan gelişi yani ham hali ve ocaktan çıktıktan sonraki aşaması ustanın eline geliş hikayesi ifade edilmiştir.
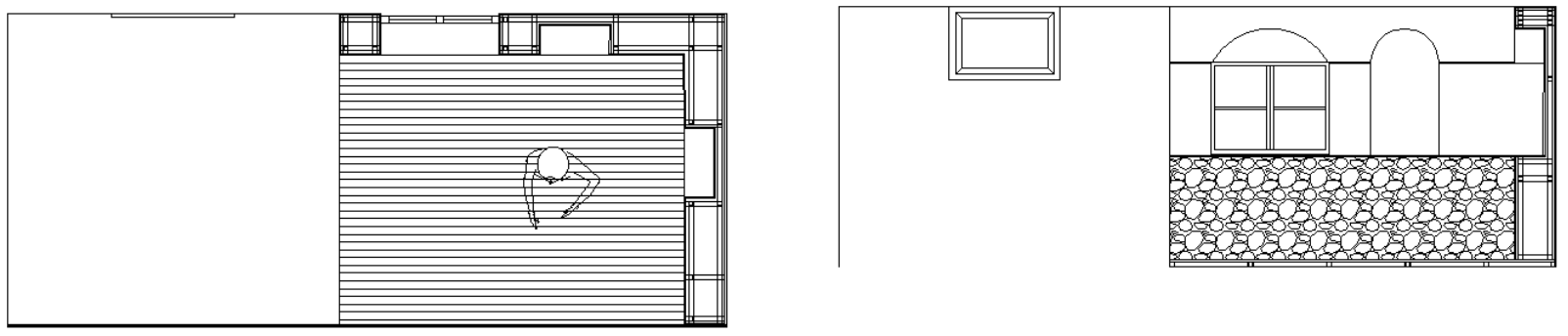

Şekil 15. Ana Eyvan taş işçiliğini anlatan canlandırma detayı çizimi

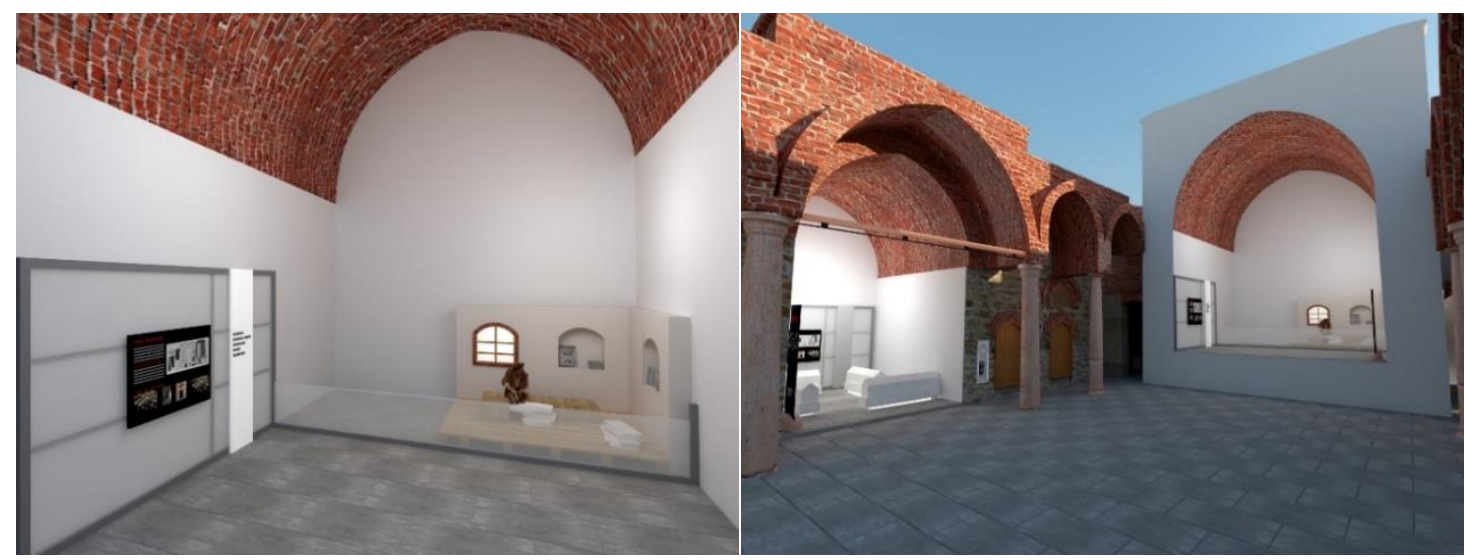

Şekil 16. Ana Eyvana giriş kapısından bakış

Yan eyvan 1'de (Sol yan eyvan) koleksiyonda yer alan 4 adet lahidin sergilenmesi için düzenleme yapılmıştır (Resim). Ayrıca, odanın bu bölümde Akşehir'den yurt dışına kaçırılan ahşap mezar sandukalarının görsel fotoğrafları, çizimlerle desteklenerek bulundukları müze ve nasıl yurt dışına kaçırıldıklarının anlatıldığı bir pano tasarımı önerilmiştir (Şekil 17). 

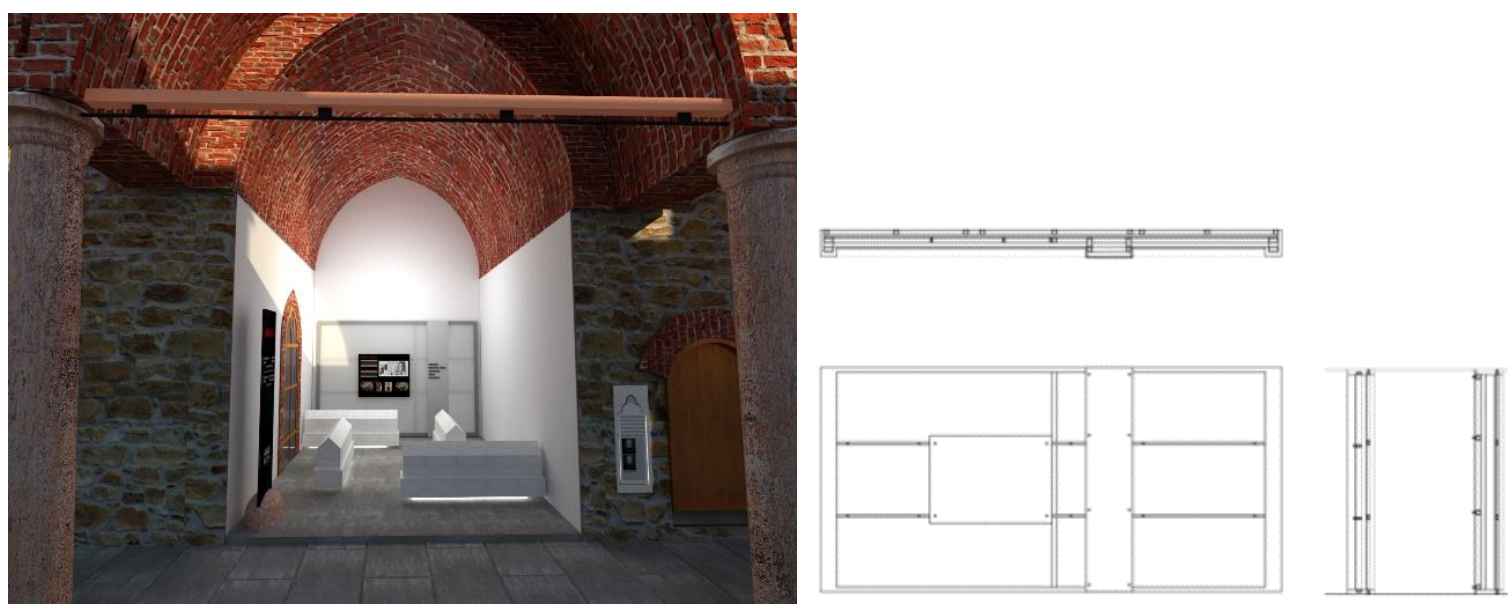

Şekil 17. Yan Eyvana avludan bakış ve pano detayı çizimi

Yan eyvan 2'de (Sağ yan eyvan) Selçukludaki eğitim sistemi ve medresenin canlandırılması yapılımıştır. Medresede talebe müderris ilişkisi, önünde bir rahlede minyatürlü bir büyük el yazma okunurken verilebilecek şekilde hazırlanması belirtilmiştir.

Oda 1 ve oda 2 (Figürlü Mezar Taşları Bölümü)'de müze envanterinde yer alan ve gruplandırılan figürlü mezar taşları sergilenecektir. Bu sergilemede mezar taşlarının tipolojik alanına göre sergilenmesi sağlanacaktır. Oda 1'de erkek mezar taşları, oda 2'de kadın mezar taşları yerleştirilecektir. Sergilenen mezarların Osmanlıca yazımları ve tercümeleri yan yana bir pano içerisinde tasarlanmıştır (Şekil 18).
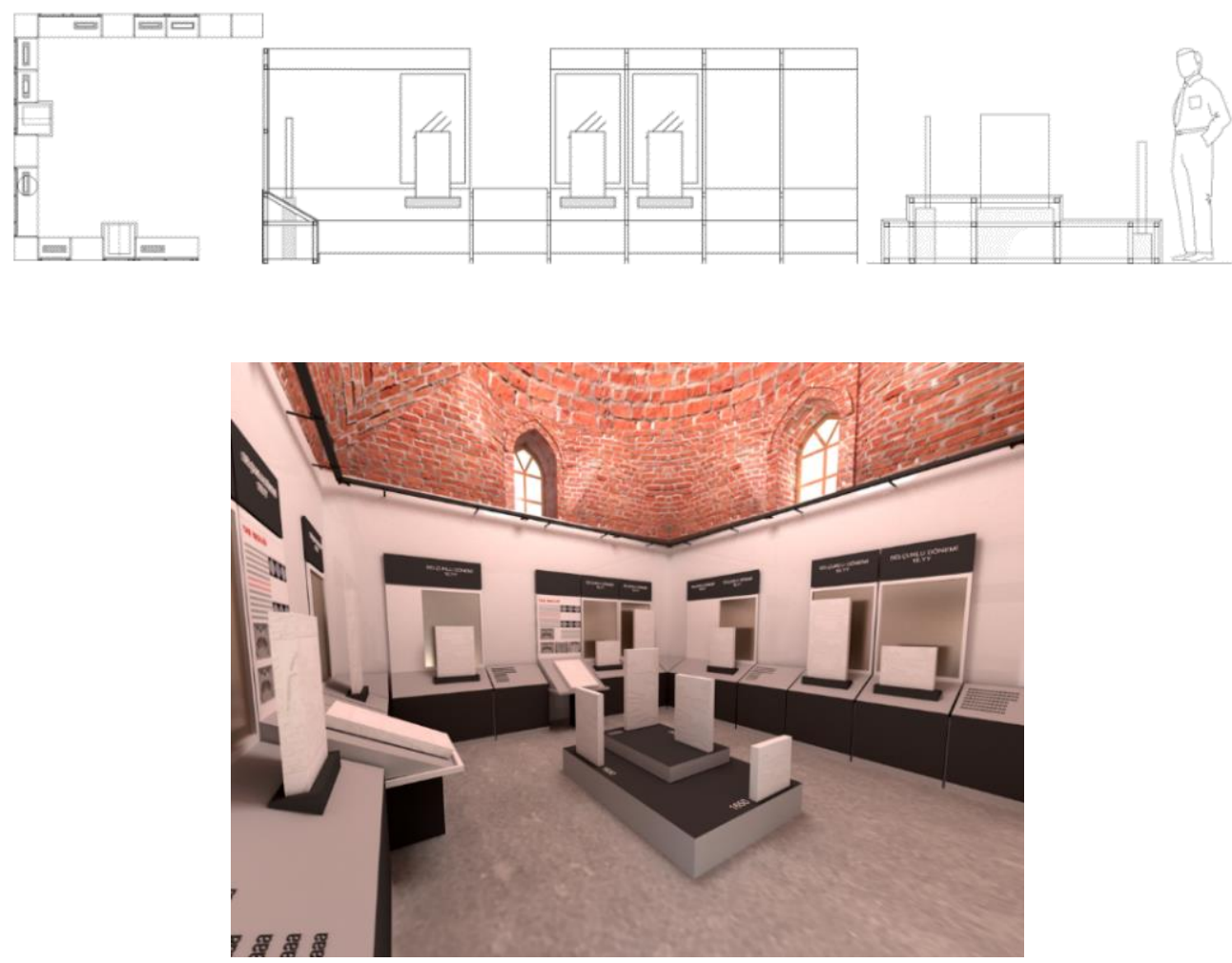

Şekil 18. Oda 1 ve 2'nin genel görünüşü ve detayı

Oda 3 (Çini Odası) duvarında müze arşivinde bulunan çinilerde değerlendirilmiş ve kısmi çini alanı oluşturulmuştur. Çünkü medrese binasının tavanlarında yer yer çini taşların kullanımı bulunmaktadır. Amaç bu malzemenin kullanımına atıfta bulunarak tanıtmaktadır (Şekil 19). 

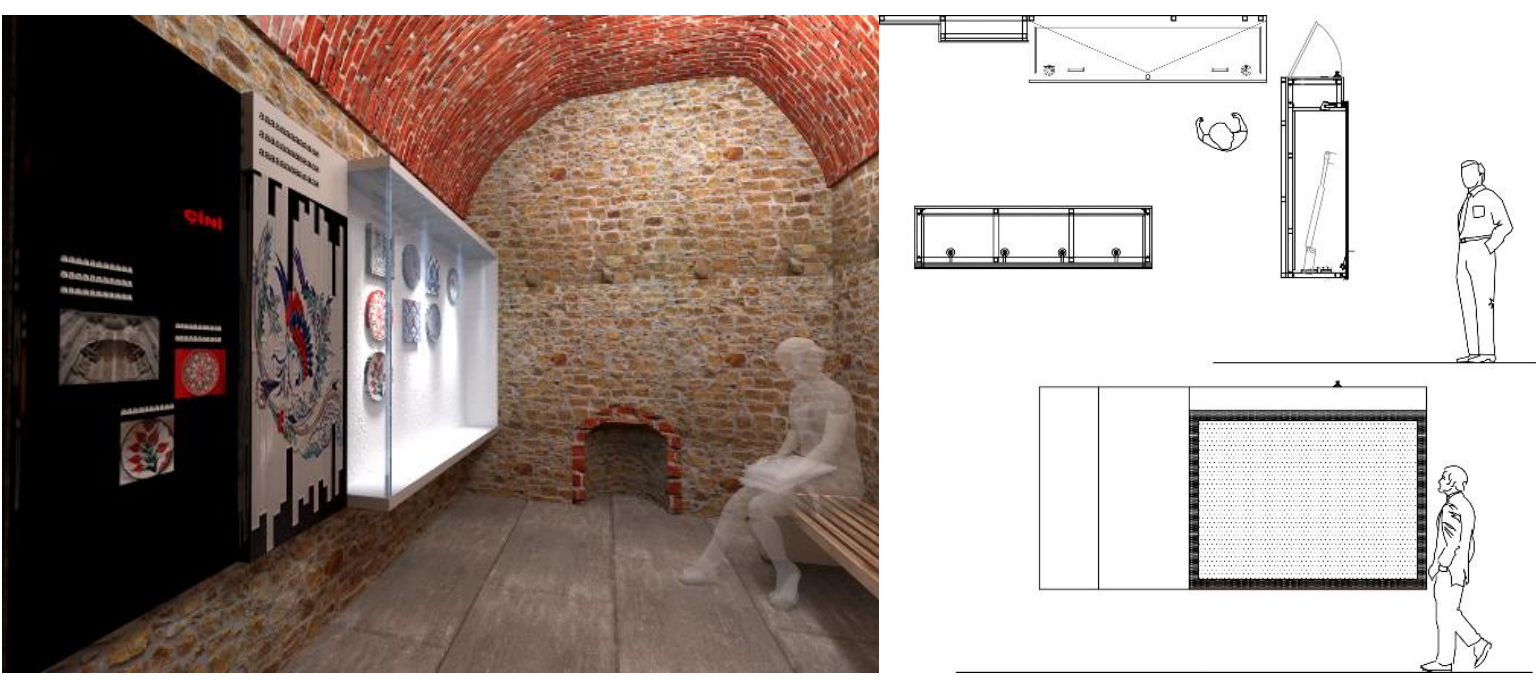

Şekil 19. Oda 3'ün genel görünüşü ve detayı

Oda 4 uyuma odası, oda 5 eğitim odası olarak mizansen canlandırılacaktır. Oda 4'de medresede kalan insanların yaşantısını; oda 5'de medresede tek başına çalışan bir öğrenciyi tanıtmak amaçlanmıştır.

Oda 6 'da Taş Medrese, tanıtım odası olarak eski ve yeni fotoğraflarla biçimlenen bir pano ile birlikte kurgulanmıştır. Ayrıca dijital bir ekranın bulunduğu bir yüzey tasarımı da yapıımıştır (Şekil 20).

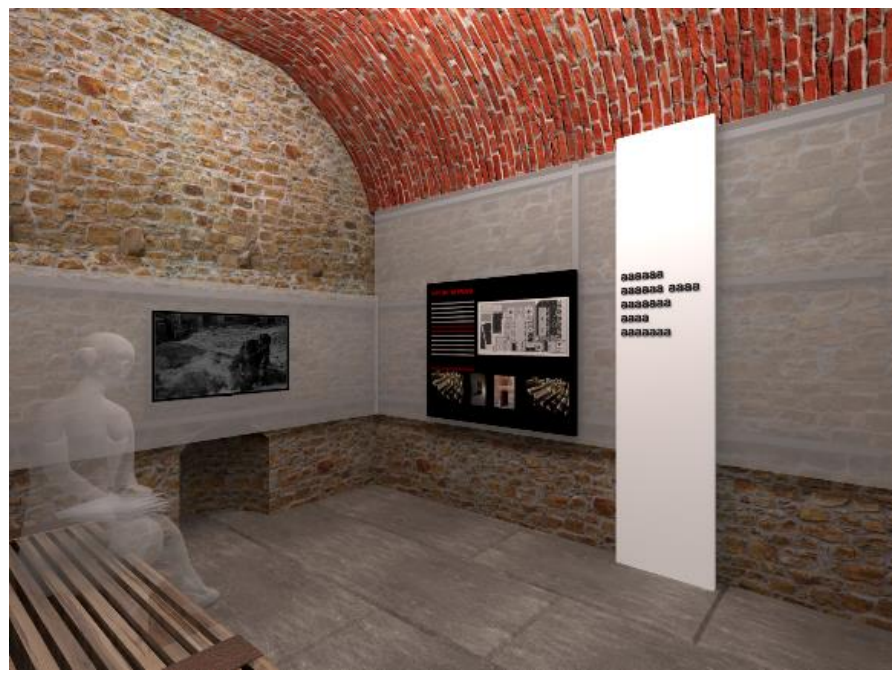

Şekil 20. Oda 6'nın genel görünüşü

Oda 7 satış ofisi, oda 8 bekçi odası, oda 9 temiz depo olarak kurgulanmıştır. Oda 10 ise çilehane olarak mizansen olarak canlandırılacaktır.

Türbe mekanında müze arşivinde yer alan Orhan Gazi'nin Kızı (Efendire Hatun), Nasreddin Hoca'nın Kızı (Melike Hatun) ve Şeyh Bedreddi'nin kızının mezar taşları manidar şekilde sergilenecektir. Bu nedenle burası üç kızlar odası olarak adlandırılmıştır. Bir bilgi panosunda türbenin plan ve mimari özellikleri hakkında bilgi de yer alacaktır (Şekil 21). 


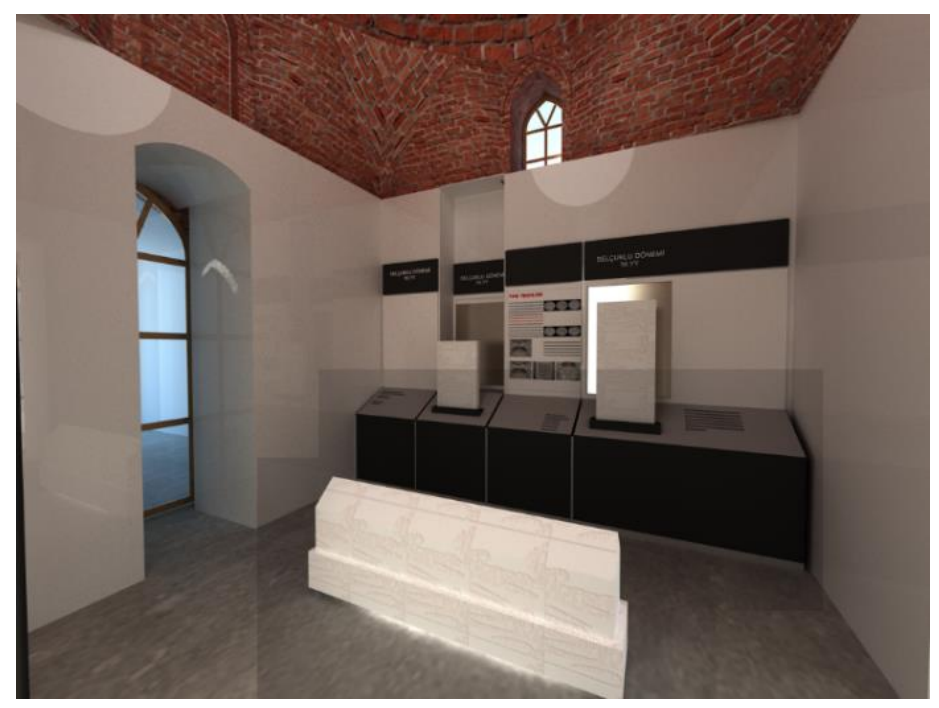

Şekil 21. Türbenin genel görünüşü

Türbe Eyvanı, müze görevli odası olacaktır. Mekânın ana caddeye bakan cephesi şeffaf camla kaplanacaktır. Mekanın kuzey duvarındaki çinilere dikkat çekilecek ve bu noktalarda gece aydınlatılması sağlanacaktır. Mekanın kuzeyinde türbe mekanına pencere açılacak bu pencere ile türbe, eyvan ilişkisi kurulacaktır. Açılacak olan pencere altında yer alan kripta (Cenazelik) bölümüne iniş merdivenleri gece için ışıklandırılacaktır. Müze kitaplığı (darülkura), kütüphane ve çalışma odası olarak işlevlendirilecektir. Yapının avlusuna ziyaretçiler için bir oturma düzeni hazırlanmıştır. Avluya yapılacak havuz ile oturma birimleri ilişkisi kurulacaktır. Avlu ile medrese odaları arasında küçük mimari buluntuların sergilenmesi planlanmıştır.

Sundurma 1, medresenin kuzeyinde yer almaktadır ve depo işlevi görecek şekilde kurgulanmıştır. Estetik değeri düşük mezar taşları ve diğer mimari plastikler burada sergilenecektir (Özel bir alan olacağı için çalışma yapan veya alanında uzmanlara hitap etmektedir). Sergilenecek mezar taşları sıkı ve görünecek şekilde sundurmaya yerleştirilecektir.

Sundurma 2, medresenin doğusunda bulunmaktadır ve burada İslami döneme ait mezar taşları sergilenecektir. Sergileme elamanları, arkalı önlü olarak iki bölümden oluşmaktadır. Özellikle mezar taşlarının açıklamalarının çizimlerle desteklenecek şekilde yapılması belirtilmiştir. Sundurma 3, dönemsel sıralamasına göre arka girişten itibaren Roma- Bizans Dönemi şeklinde yerleştirilecektir. Sundurmanın arkasındaki duvar da sergi amaçı kullanılacaktır. Sundurmada sütun başlıkları, kaideler ve sütunların, mezar steller, kısmi lahitler ve mimari plastikler (Arşitrav, lento, söve vb.) yer alacaktır Sergilemede mimari parçaların önemli olanları çizim ve belgelerle anlatılacaktır (Şekil 22). 

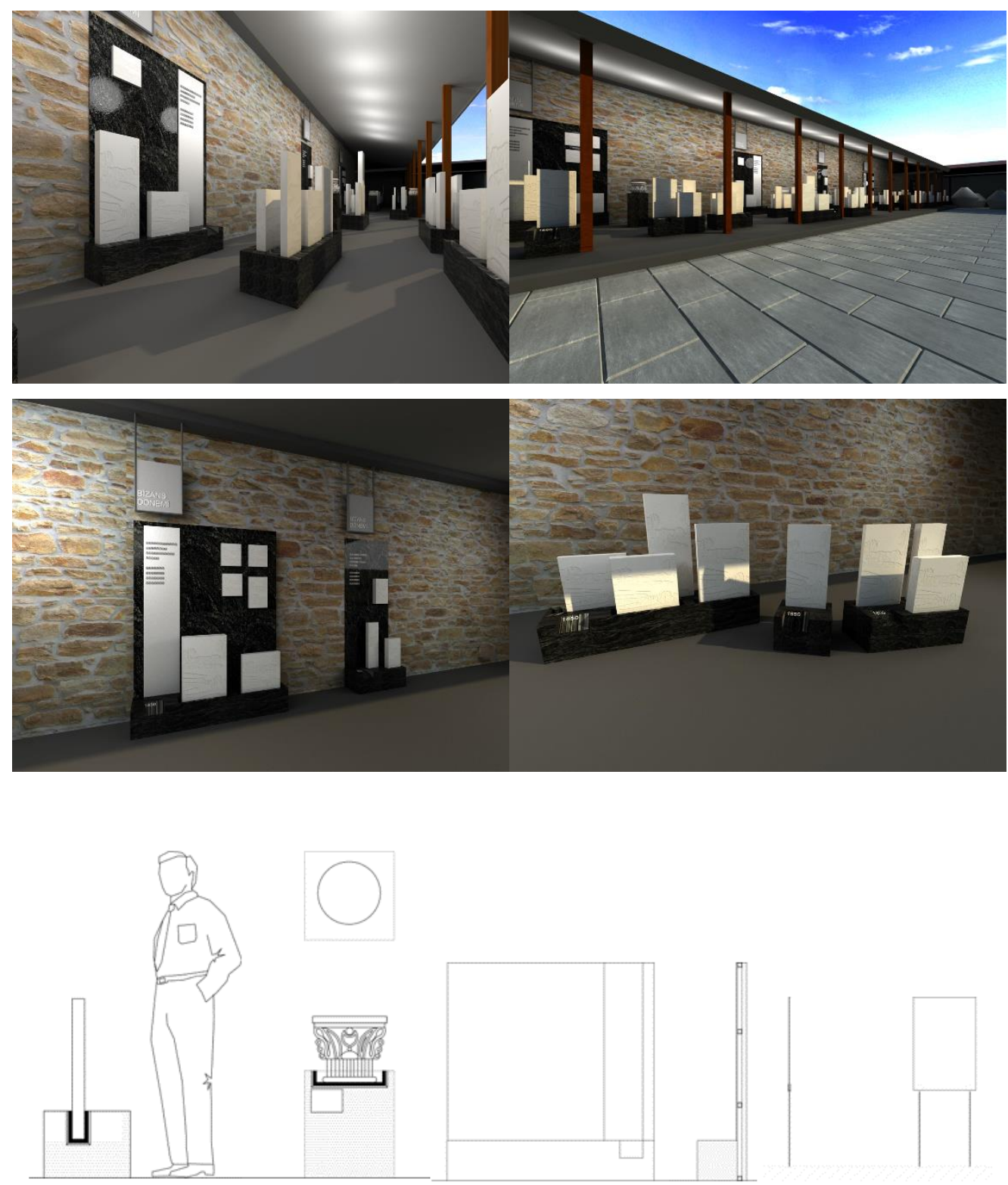

Şekil 21. Sundrma 2 ve 3'ün genel görünüşü ve detayı

\section{Sonuç}

Kültür varlıkları, geçmişimizi yansıtan önemli eserler olup, değişen koşullara bağlı olarak günümüz şartlarına entegre olmaları gerekmektedir. Bu nedenle mimarinin sürdürülebilirliği, için koruma ve restorasyon çalışmaları yapılmalı, gerekiyorsa yeniden işlev verilerek yapı hem topluma kazandırılmalı, hem de yok olması önlenmelidir. Medrese yapıları da yapıldıkları dönemler için mimari açıdan simgesel bir yapı özelliği taşımakta olup, günümüzde ise işlevsel açıdan uyum sağlayamamaktadır. Bu nedenle yeniden işlevlendirilerek toplum yaşamına entegre olmaları sağlanmalıdır. Bu fonksiyonlar arasında hem konumu, hem de m2'si aynı zamanda bir dönemi yansıttıkları için sergilenmesi gereken eser niteliği taşımaları nedeniyle sıkıkla ülkemizde müze olarak kullanıldıkları görülmüştür. Bu bağlamda bu tür yapıların müze işlevi amacıyla kullanımı sırasında özgünlüğünün bozulmamasına dikkat edilmelidir.

Çalışma kapsamında Akşehir Taş Medresenin, Akşehir Taş Medrese Taş Eserler müzesi olarak yeniden işlevlendirilmesi; teşrif ve tanzim projesi ile önerilen iç mekan çalışmaları değerlendirilmiştir (Şekil 23). Yapılan inceleme de Taş Medresenin farklı yıllarda çeşitli onarımlar geçirdiği görülmüştür. Bu bağlamda geçmiş dönemde mekânsal anlamda orijinal plandan uzaklaşması nedeniyle 2009 yılında kabul edilen restorasyon projesine göre yeni bir plan önerilmiş, restitüsyon raporunda yer alan gerekçeleriyle de kabul edilmiştir. Bu bağlamda; geçmiş yıllardaki onarımlar sırasında eklendiği düşünülen bir oda yerine 
sağ tarafa bir eyvan eklenmiştir. Ayrıca türbe eyvanı ve giriş kısmı yeniden kurgulanmıştır. Bu aşamadan sonra, müze olarak kurgulanması istenen yapıya kimlik katma amacıyla teşrif ve tanzim projesi hazırlanmaya başlamıştır.

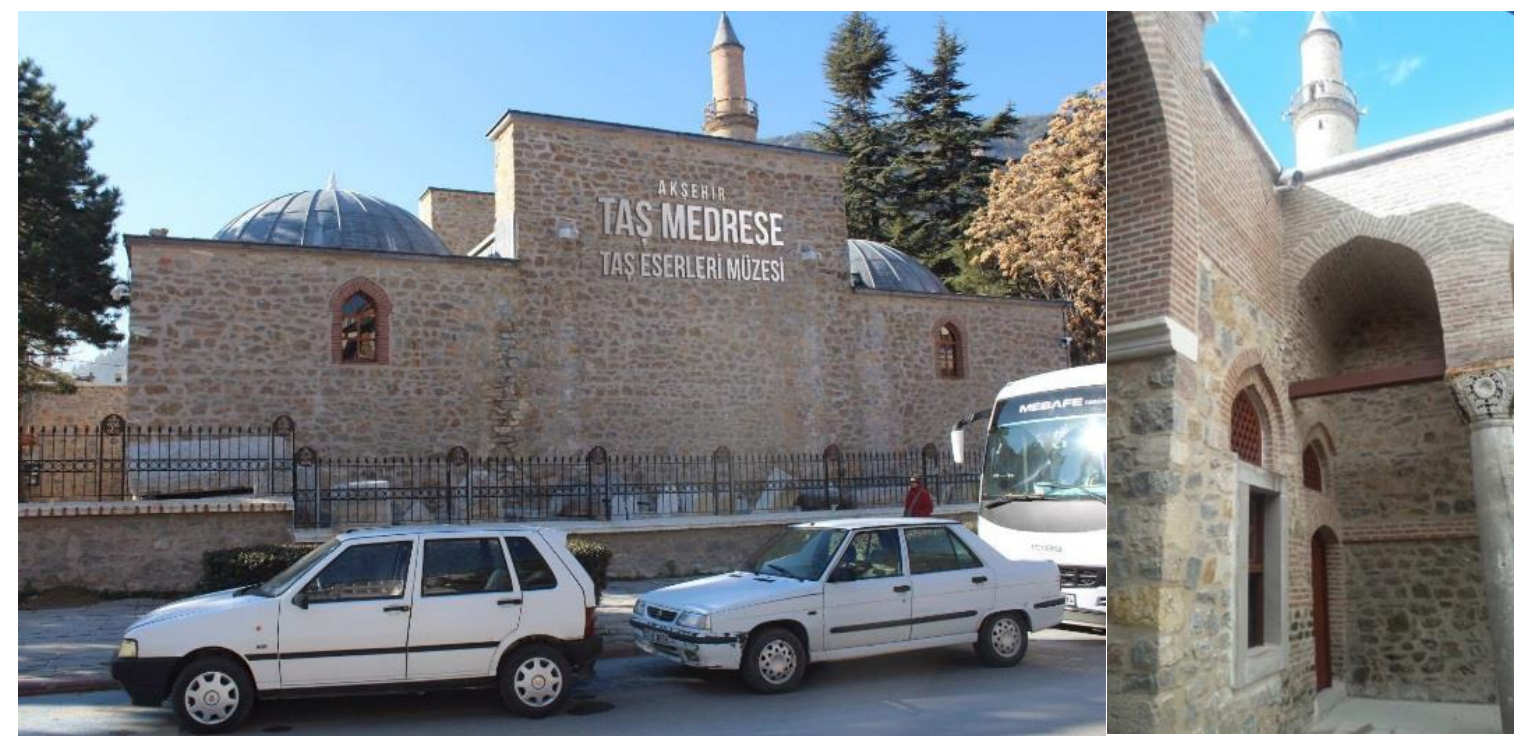

Şekil 23. Akşehir Taş Medrese Taş Eserler müzesi görünüş

TC. Kültür ve Turizm Bakanlığı Konya Kültür Varlıklarını Koruma Bölge Kurulu'na sunulan proje ile müzenin amacı belirlenerek, ziyaretçilerin sirkülasyonu için bir senaryo hazırlanmıştır. Bu kapsamda iki aşama süreç yönetilmiştir. Illk aşama araştırma ikinci aşama senaryo ve projelendirme bölümlerinden oluşmaktadır. Araştırma, hem yapının tarihi değeri hem de mekânsal özelliklerinin ele alındığı evredir. Ayrıca bu evrede koleksiyon seçimleri yada koleksiyona alınan ürünlerin özellikleri de ortaya konmaktadır. Yapılan çalışmalar tasarımcının bu konuda deneyimi ve hassasiyetine katkı sağlamaktadır. Senaryo ise, yapının yeni işlevine entegre olduğu; mekânının organizasyonuna dair seçeneklerin ele alındığı en doğru organizasyonun belirlenmesi ile de uygun teşhir ve tanzim tasarımlarının kurgulandığı aşamadır. Taş eserler müzesi içerisinde ağırlıklı olarak mezar taşı, lahit gibi taş eserleri tanıtan aynı zamanda gerçek işlevi olan medrese eğitimini öne çıkaran bir konsept geliştirilmiştir, sonrasında ise uygulamaya geçilmiştir (Şekil 24, 25, 26, 27, 28).

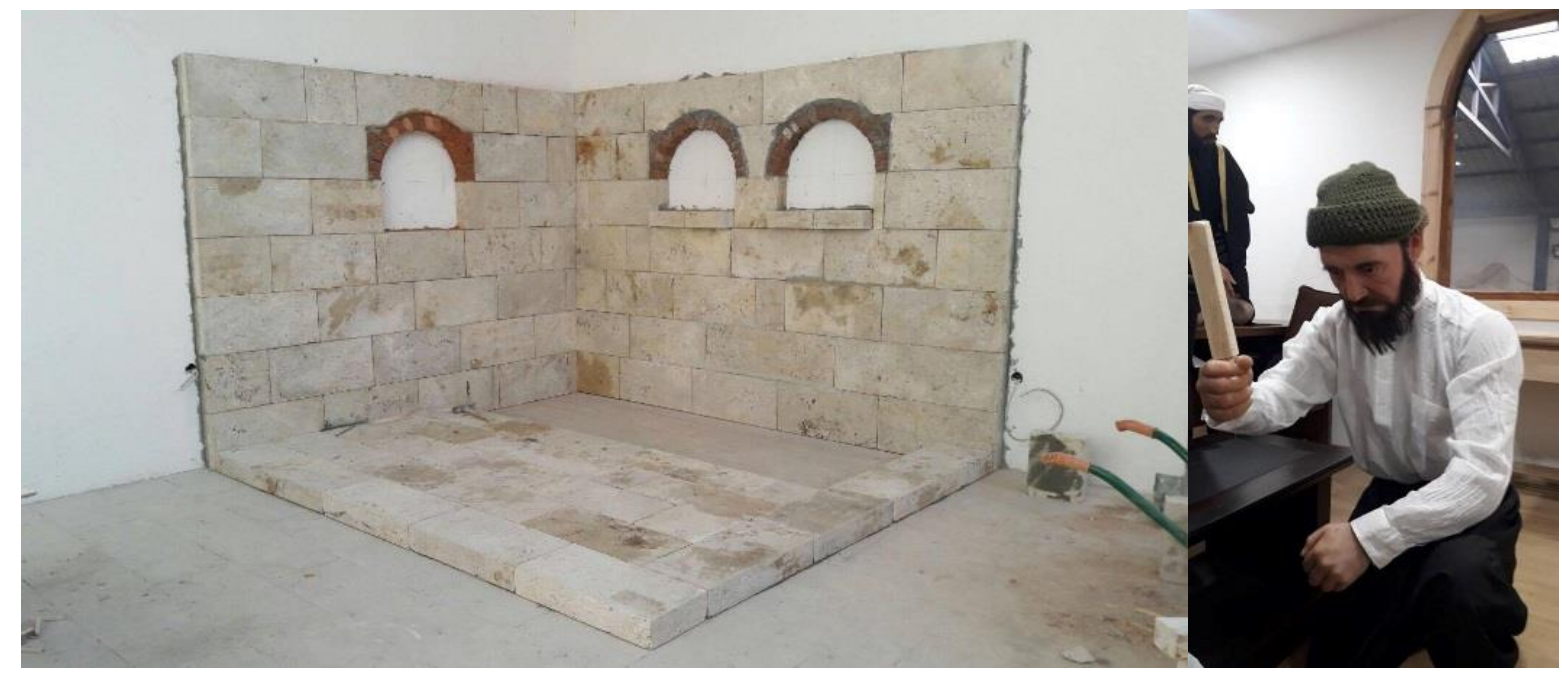

Şekil 24. Ana eyvanın uygulamasından görünüş 


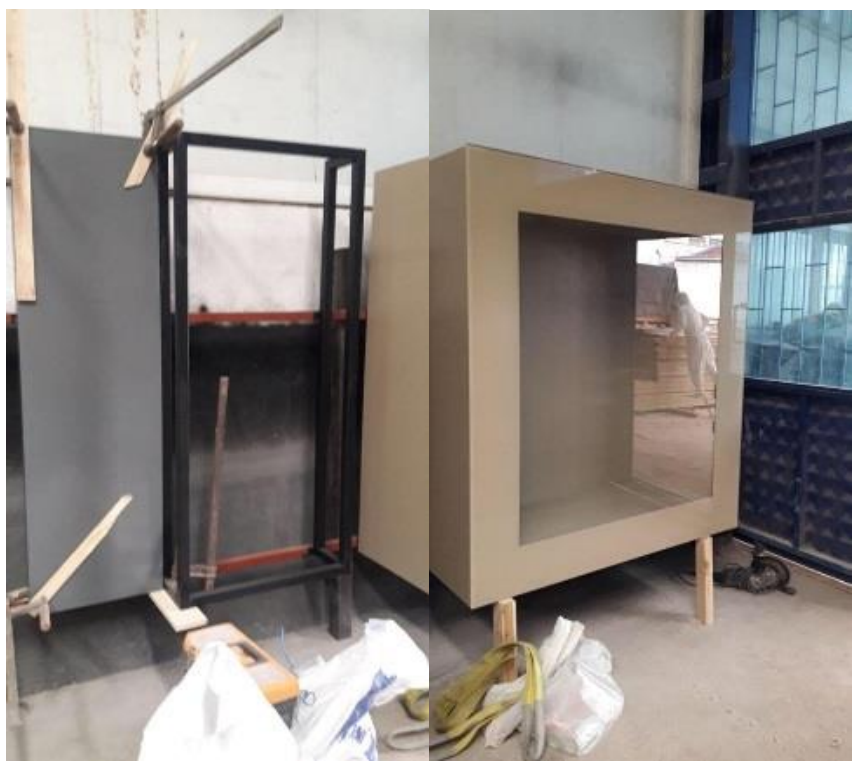

Şekil 25. Oda 3'de yer alan çini taşlarının sergileme donatısı ve anlatı panosu uygulama süreci

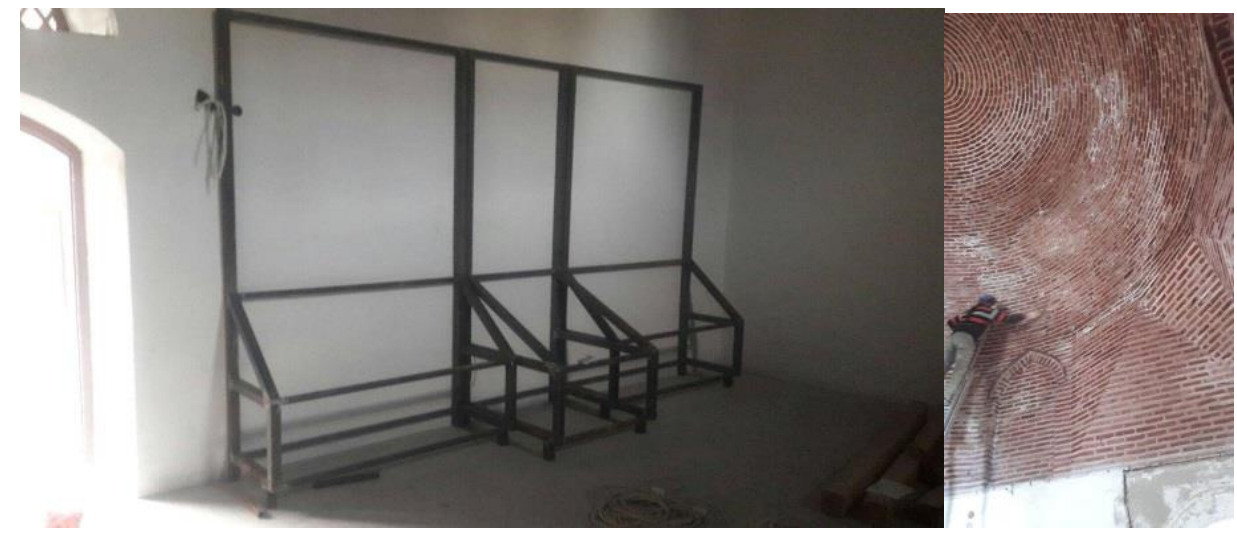

Şekil 26. Oda 1-2 figürlü taş sergileme donatısı ile tavan uygulama süreci

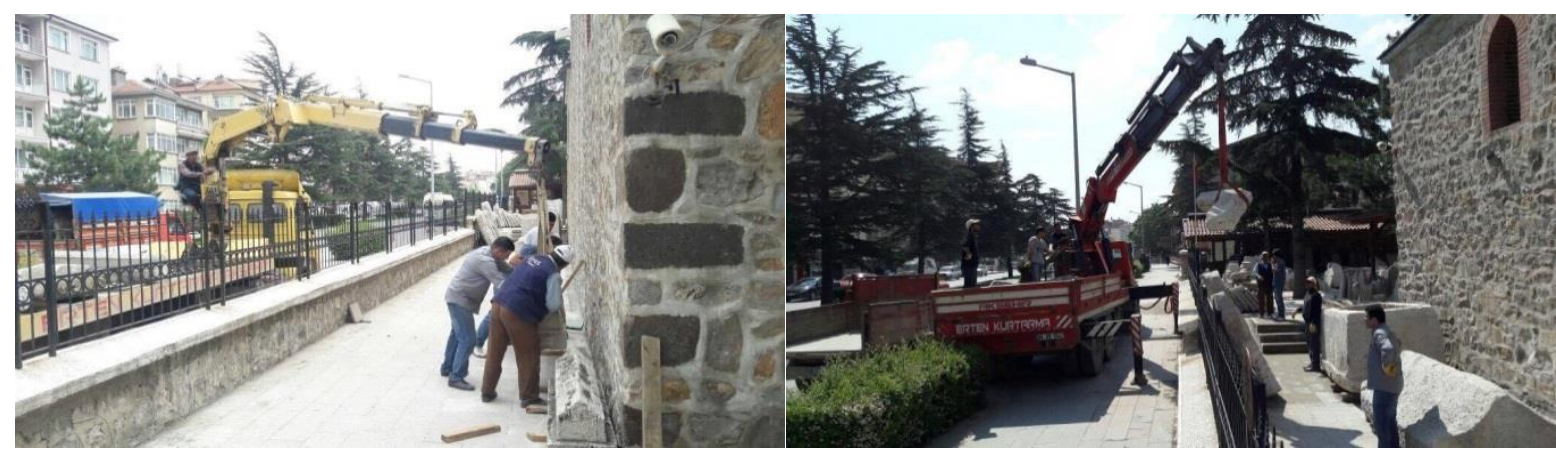

Şekil 27. Sundurma 1'de uygulama süreci

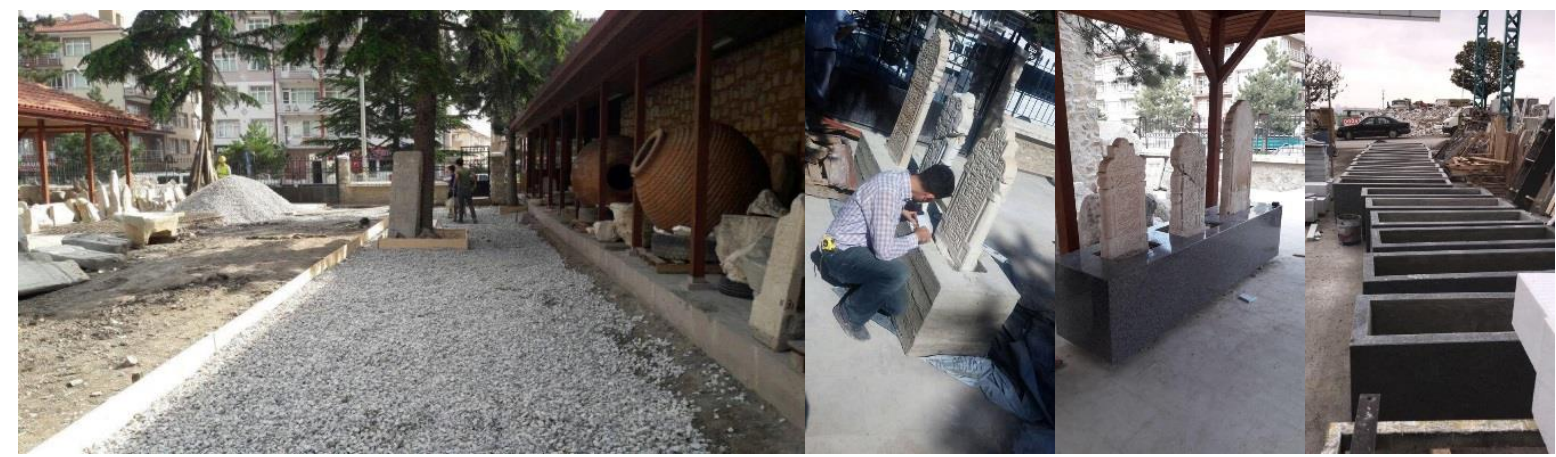

Şekil 28. Bahçe ve Sundurma 2 ve 3' de uygulama süreci 
Tasarım sürecine ait şemanın, bu ve benzeri çalışmalar için tasarımcılara katkı sağlayacağı düşünülmektedir. Tüm çalışmalar, bir kültür varlığı olan medrese binasının yeniden kullanımı amacıyla dönüşüm sürecinde restitüsyon ve restorasyon çalışmalarının önemine vurgu yapmıştır. Ayrıca teşrif ve tanzim projelerinin hangi aşamalarda hazırlandığını ortaya koymayı hedeflemiştir.

\section{Teşekkür}

Bu çalışma TC. Kültür ve Turizm Bakanlığı Konya Kültür Varlıklarını Koruma Bölge Kurulu'nun 06.1.2015147 toplantı tarihi ve numaralı, 06.11.2015-3232 karar tarihi ve numaralı ekte kurul kararı ile de kabul edilmiş proje çalışmasını tanıtmaktadır. Baloğlu Mimarlık ve Mühendislik Restorasyon İnşaat San. Tic. Ltd. Şti.'ne danışmanlık yapmakta olup teşhir ve tanzim proje çalışmasının tasarımı Yrd. Doç. Dr. Şebnem ERTAŞ'a aittir.

\section{Kaynaklar}

Altınoluk, Ü. (1998). Binaların Yeniden Kullanımı s.15,19,20.

Altun, A. (1998). Orta Çağ Türk Mimarisinin Ana Hatları İçin Bir Özet, s.78, Ankara.

Aslanapa, O. (1973). Türk Sanatı, S.108, İstanbul.

Dedehayır, H. (2013). “Kent Tarihi Müzeleri Ve Arşivleri”, Çekül Vakfı-Tarihi Kentler Birliği Yayınları, İstanbul.

Demiralp, Y. (1996). Akşehir Ve Köylerindeki Türk Anıtları, s.57, Ankara.

Emekli, G. (2005). Avrupa Birliği'nde Turizm Politikaları Ve Türkiye'de Kültürel Turizm, Ege Coğrafya Dergisi, 14, s. 99-107, ìzmir.

Ertaş, S. (2016). Kişisel Fotoğraf Arşivi.

Friedrich, S. (1896). Reise in Kleinasien, s.20-21, Berlin.

Öztekin, O. A. (2014). Müze Kavramı Ve Müze Yapılarının İ̧̧ Mekanlarının İstanbul' Dan Örneklerle İncelenmesi, Yüksek Lisans, Haliç Üniversitesi, Fen Bilimleri Enstitüsü, Konya.

Karpuz, H. (1994). Anadolu Selçuklu Mimarisi Ders Notları, s.51, Konya.

Köroğlu, H. (1999). Konya Ve Anadolu Medreseleri, s.131, Konya.

Kuran, A. (1969). Anadolu Medreseleri, Cilt:1, s.79-82, Ankara.

Restitüsyon Raporu, (2009). Ceray Mimarlık ve Restorasyon, Konya.

Restorasyon Tadilat Raporu, (2009). Baloğlu Mimarlık, Konya.

Sarre, F. (1896). Reise in Kleinasien, s.20-21, Berlin.

Sinan, S. (2011). Tarihi Binaların İşlev Değişimi'nin Yıldız Sarayı Müzesi Örneği Üzerinden Değerlendirilmesi, Yüksek Lisans, Mimar Sinan Güzel Sanatlar Üniversitesi, Fen Bilimleri Enstitüsü, Konya.

Tanaç Zeren, M. (2010). İzmir'de Sefarad Mimarisi Ve Sinagogları, Yalın Yay., İstanbul.

Yaldız, E. (2003). Konya'daki Medrese Yapılarının Yeniden Kullanım Koşullarına Göre Değerlendirilmesi, Yüksek Lisans, Selçuk Üniversitesi, Fen Bilimleri Enstitüsü, Konya.

Üçer, N. 2011, Tarihi Dokuların Sürdürülebilirliğinde Turizm Kaynaklı Değişimlerin Etkileri: Kuşadası Dağ Ve Camii-Kebir Mahalleleri Örneği, Yüksek Lisans, Dokuz Eylül Üniversitesi, Fen Bilimleri Enstitüsü, İzmir.

URL-1. https://En.Wikipedia.Org/Wiki/Beethoven_House (Erişim Tarihi:27.12.2016).

URL-2. http://Blog.Biletbayi.Com/Salzburg-Rehberi.Html (Erişim Tarihi:24.12.2016).

URL-3. http://www.arasikackm.com/konya-meram_aksehir_arasi (Erişim Tarihi:02.08.2017). 